\title{
PERANCANGAN SISTEM INFORMASI PENGOLAHAN DATA NILAI SISWA BERBASIS WEB DI SMKN 1 PRAYA
}

\author{
Nizar Haris' ${ }^{1}$, Khairul Imtihan², Maulana Ashari ${ }^{3}$ \\ Program Studi Sistem Informasi \\ Sekolah Tinggi Manajemen Informatika dan Komputer (STMIK) \\ Jln. Basuki Rahmat No. 105 Praya Lombok Tengah \\ ${ }^{1}$ nizar_haris@yahoo.com, ${ }^{2}$ khairulimtihan31@gmail.com, ${ }^{3}$ aarydarkmaul@gmail.com
}

\begin{abstract}
ABSTRAK
Sistem informasi pengolahan data nilai siswa di SMKN 1 PRAYA saat ini belum sepenuhnyan terkomputerisasi. Dalam mengolah data nilai siswa, saat ini masih dilakukan secara manual, yaitu masih ditulis di buku raport dan leger nilai sehingga banyak waktu dan tenaga yang diperlukan untuk memproses tugas tersebut, sehingga membutuhkan waktu yang sangat lama dalam pengerjaannya.

Metode yang digunakan adalah metode waterfall. Metode ini mencakup tahapan yaitu Analisis dan definisi, Perancangan sistem dan perangkat lunak, Implementasi dan pengujian unit, Integrasi dan pengujian sistem, serta operasi dan pemeliharaan sistem, di sistem informasi pengolahan data nilai siswa berbasis web ini yang menghubungkan antara komputer dan guru melalui internet.

Hasil dari penelitian adalah suatu sistem informasi untuk pengolahan data nilai siswa dengan menggunakan media komputer yang akan mempermudah mencatat data nilai siswa sehinnga menjadi media yang efektif bagi perkembangan pendidikan, khususnya di SMKN 1 PRAYA. Pengolahan data nilai siswa secara otomatis sehingga proses informasi dapat tersaji dengan cepat.
\end{abstract}

Kata Kunci: $P H P, M y S q L$, Waterfall.

\begin{abstract}
Student data processing information system in SMKN 1 PRAYA is not yet fully computerized. In processing the student value data, it is still done manually, which is still written in the book report cards and legend values so much time and energy needed to process the task, so it takes a very long time in the process.

The method used in this final project is waterfall method. This method includes the stages of Analysis and definition, System and software design, Implementation and unit testing, Integration and system testing, and operation and maintenance of the system, in the information processing system student value web-based students who connect between computers and teachers via the internet.

The result of this final project is an information system for data processing of student value by using computer media which will make it easier to record student value data become an effective media for education development, especially in SMKN 1 PRAYA. Automatic student data processing so that the information process can be presented quickly.
\end{abstract}

Keywords: PHP, MySql, Waterfall.

\section{Pendahuluan}

\subsection{Latar Belakang}

Sekolah adalah salah satu sarana organisasi dalam memberikan pelayanan kepada masyarakat dalam bidang pendidikan. Salah satu bagian terpenting dari suatu sekolah adalah siswa dan nilai siswa tersebut. Dalam satu sekolah ada ratusan siswa dan masing-masing mempunyai nilai yang berbeda-beda. Tak jarang penyimpanan nilai siswa dicatat dan disimpan secara konvensional. Sehingga membutuhkan waktu yang sangat lama dalam pengerjaannya. Sedangkan hasil dari pengolahan data nilai siswa hanya bisa dilihat, baik oleh siswa maupun orang tua siswa hanya pada buku raport. (Ladjamuddin, 2013).

Sistem pengolahan data nilai siswa SMKN 1 PRAYA belum sepenuhnya terkomputerisasi, 
adapun prosedur yang dilakukan adalah menerima berkas penilaian siswa dari setiap guru mata pelajaran setelah itu dicatat dalam buku kumpulan nilai/leger dan menyalinnya kembali dalam satu buku yang disebut dengan raport.

Berdasarkan pemaparan tersebut, penulis memiliki peluang untuk mengganti sistem yang lama dengan sistem yang baru dengan membuat "PERANCANGAN SISTEM INFORMASI PENGOLAHAN DATA NILAI SISWA BERBASIS WEB DI SMKN 1 PRAYA", dengan adanya sistem baru ini diharapkan dapat membantu semua pihak yang ada di sekolah dalam melakukan pengelolaan dan penyimpanan data nilai siswa.

\subsection{Rumusan Masalah}

Berdasarkan latar belakang tersebut maka dapat dirumuskan bahwa permasalahan yang ada adalah sebagai berikut:

1. Bagaimana membangun aplikasi berbasis web yang dapat memudahkan proses pengolahan nilai siswa?

2. Bagaimana update, rekap dan pencarian nilai siswa serta memberikan informasi (pengumuman) yang baik yang dapat diakses dengan mudah dan efisien menggunakan website?

3. Bagaimana mengatasi sulitnya penyampaian informasi nilai pada SMKN 1 PRAYA?

\subsection{Tujuan Penelitian}

1. Menghasilkan sistem informasi nilai berbasis web yang dapat mengolah nilai siswa, pencarian, meng-update, menyimpan, rekap nilai siswa dan laporan nilai yang dapat di akses dengan mudah dan efektif.

2. Membuat sistem informasi nilai yang dapat dijadikan sumber promosi dan memberikan informasi (pengumuman) pada pihak internal maupun eksternal.

3. Membuat proses pengolahan nilai siswa menjadi lebih mudah dan fleksibel.

\subsection{Batasan Masalah}

Berdasarkan rumusan masalah yang dipaparkan di atas, beberapa hal batasan masalah antara lain:

1. Sistem ini hanya dapat diakses oleh admin, kepala sekolah, guru dan siswa yang ada di SMKN 1 PRAYA.
2. Sistem informasi pengolahan data nilai siswa ini khusus menangani pengelolaan nilai siswa yang ada di SMKN 1 PRAYA.

\subsection{Manfaat Penelitian}

1. Pengolahan nilai siswa menjadi lebih mudah dengan adanya sistem informasi pengolahan data nilai berbasis web ini.

2. Pengolahan data nilai siswa yang sebelumnya secara manual sekarang menjadi terkomputerisasi karena adanya sistem informasi pengolahan data nilai siswa berbasis web tersebut.

3. Memudahkan pihak sekolah khususnya bagi para guru dalam mengolah data nilai siswa yang ada di SMKN 1 PRAYA.

4. Membantu kinerja para guru di SMKN 1 PRAYA dalam pencatatan nilai siswa yang cepat dan efisien.

\subsection{Metodologi Penelitian}

1. Metode Observasi

Peneliti langsung melakukan pengamatan ke lapangan untuk mengetahui dan mengamati bagaimana sistem pengolahan nilai siswa yang ada di SMKN 1 PRAYA tersebut.

2. Metode Wawancara

Pengumpulan data dengan cara peneliti melakukan tanya jawab atau bertanya langsung pada pihak-pihak yang terkait yang menjadi narasumber peneliti dalam mendapatkan informasi.

\section{Tinjauan Pustaka}

(Kusuma, Susy Wardani (2013), telah melakukan penelitian, diantaranya penelitian dengan judul "Sistem Informasi Pengolahan Data Nilai Siswa Berbasis Web Pada Sekolah Menengah Atas (SMA) Muhammadiyah Pacitan". Kelebihan dari penelitian ini yaitu penginformasian data nilai siswa sudah menggunakan web sehingga informasi nilai siswa dapat langsung diterima oleh siswa melalui komputer lain yang terkoneksi dengan internet.

Novi Haryo Kusumo (2014) telah melakukan penelitian dengan judul "Sistem Informasi Penglahan Penilaian Siswa di SMA Negeri 1 Karanganyar Dalam penelitian itu disebutkan bahwa telah mempunyai sistem informasi pengolahan nilai berbasis Microsoft excel akan tetapi sistem aplikasi tersebut hanya mengakomodasi penilaian untuk tiap-tiap kelas dan single user sehingga hanya digunakan oleh tim 
kurikulum dan itu menjadi tanggung jawab yang besar bagi tim kurikulum untuk menginputkan semua nilai setiap akhir semester.

(Khotimah, Iriani (2014), telah meakukan penelitian, diantaranya penelitian dengan judul "Sistem Informasi Pengolahan Data Nilai Siswa Berbasis Web Pada Madrasah Tsanawiyah Al Muhajirin Kalak Donorojo", Sistem ini yang diyakini mampu memberikan kontribusi positif dalam meningkatkan kinerja guru mapel dan wali kelas yaitu dengan membuat aplikasi penilaian menggunakan php dan Database menggunakan MySql.

Ubaidillah (2015) telah melakukan penelitian dengan judul "Perancangan dan Implementasi Sistem Informasi Pengolahan Penilaian Data Siswa (Studi Kasus: Madrasah Tsanawiyah Negeri (MTSN) Bojonegara Puloampel)". Pada penelitian tersebut membuat program aplikasi yaitu sebuah sistem informasi penilaian siswa yang berbasis komputerisasi dan berjalan dengan teknik stand alone (PC) yang didalamnya terdapat kemudahan dalam pengoperasian dan pemeliharaan data penilaian siswa.

M. Irsan Parinduri (2016), Judul Penelitian "Sistem Informasi Pengolahan Data Nilai Siswa Berbasis Web Pada SMU Negeri 2 Medan". Pada penelitian ini bertujuan untuk memberikan suatu aplikasi sistem yang dapat digunakan dengan mudah dalam melakukan pekerjaan dan untuk mendukung dalam pengambilan keputusan.

\section{Analisa Dan Perancangan}

\section{Flowmap Sistem Yang Berjalan}

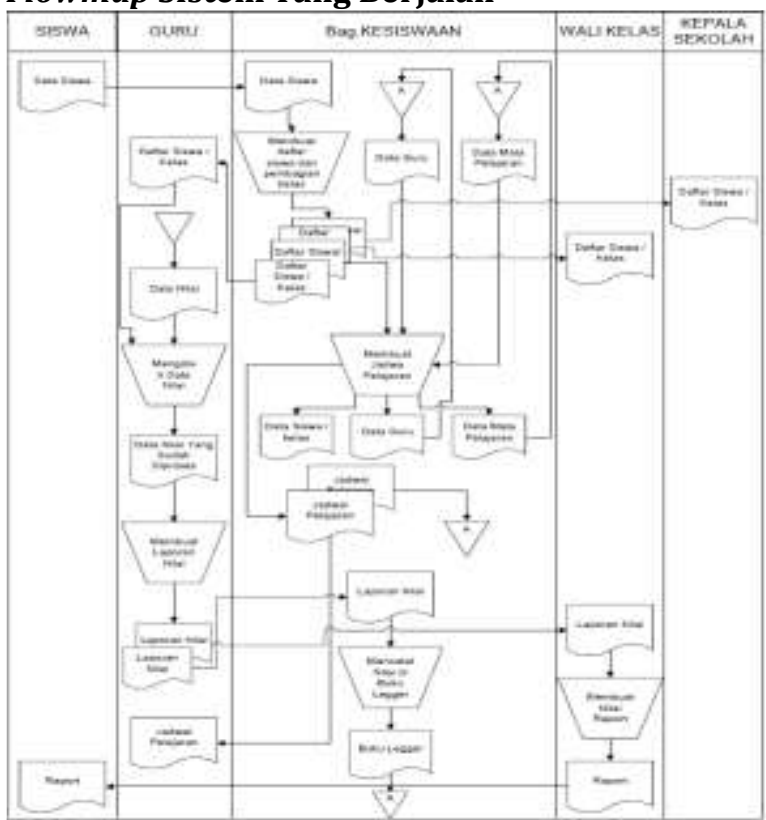

Gambar 3.1 Flowmap Yang Berjalan

\subsection{Solusi Yang Dapat Di Terapkan}

1. Rancangan alur sistem hanya memiliki satu alur sistem yaitu alur kerja bagian admin (panel administrasi).

2. Alur kerja bagian admin dimulai dari admin mengakses halaman admin dan akan masuk kehalaman login yang terdiri dari 2 (dua) kolom, yaitu username dan password, data login ini selanjutnya dicocokkan dengan data pengguna yang ada didalam database. Setelah proses login sukses, user dapat mengoperasikan halaman admin.

3. Operasi yang dimaksud meliputi menampilkan data (view), menambah data (insert), memperbaharui data (update), menghapus data (delete), membuat laporan (report) dan mencetak laporan (print).

\section{Flowmap Sistem Yang Di Usulkan}

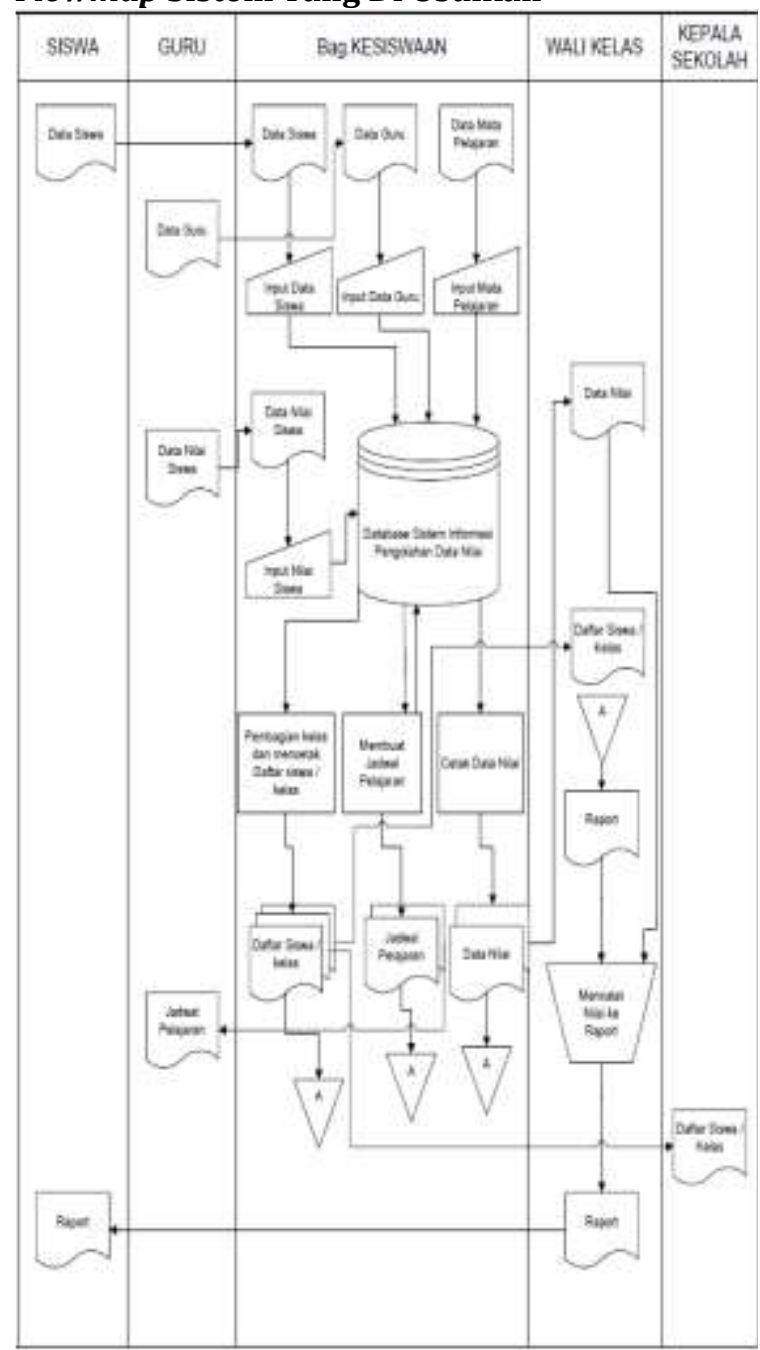

Gambar 3.2 Flowmap Usulan 


\subsection{Data Flow Diagram}

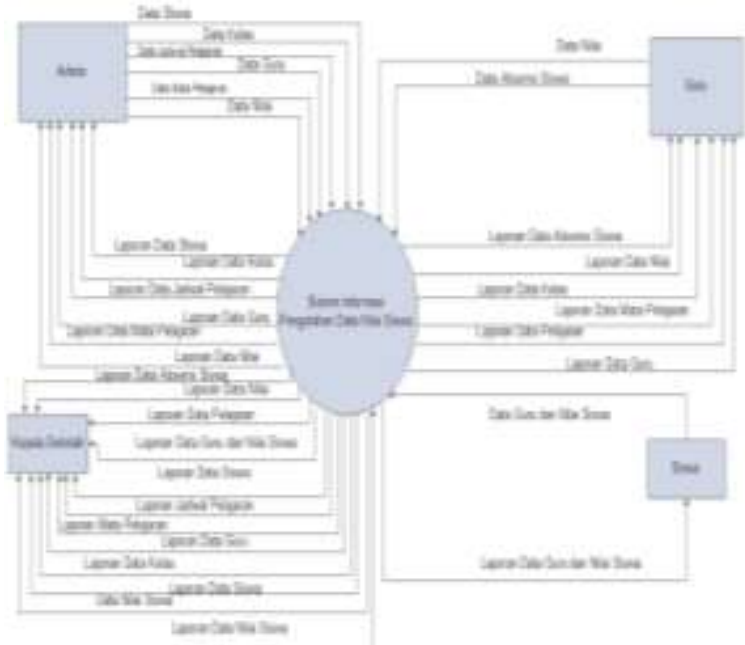

\section{Gambar 3.3 Diagram Konteks}

Dalam konteks diagram pada gambar 3.3 terdapat lima external interactor yang menunjang proses sistem informasi pengolahan data nilai yaitu, admin, Guru, Staff Akademik, dan kepala sekolah. Pada sistem yang diusulkan, peneliti membedakan level user yang akan mempengaruhi batasan layanan sistem sebagai berikut:

1. Admin, hak akses bagi admin adalah dapat melakukan insert, update, dan juga delete pada modul data siswa, data kelas, data guru, data nilai, data mata pelajaran, dan data jadwal pelajaran.

2. Guru, hak akses bagi guru adalah dapat melakukan insert, edit, dan delete pada modul data nilai dan data absensi siswa.

3. Siswa, hak akses yang diberikan siswa adalah dapat melakukan insert, edit, dan delete pada modul data pada data siswa.

4. Kepala sekolah, hak akses bagi kepala sekolah adalah dapat mencetak seluruh data yang ada di sistem.

\subsection{DFD Level 1}

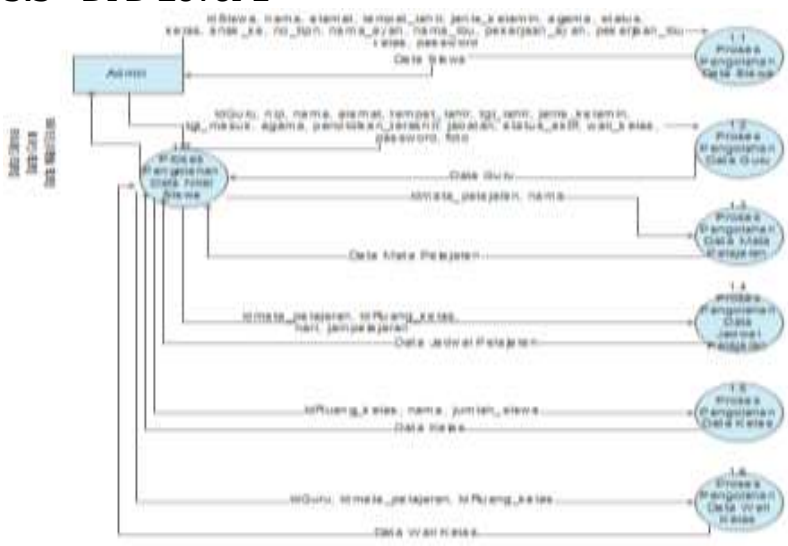

Gambar 3.4 DFD Level 1
Pada rancangan gambar 3.4 merupakan perancangan (DFD) dimana terdapat beberapa proses, yaitu proses mengelola data nilai siswa yang sesuai, pengolahan data nilai siswa yang diproses oleh sistem dan kemudian di simpan ke dalam database.

\subsection{DFD Level 2 Proses 1}

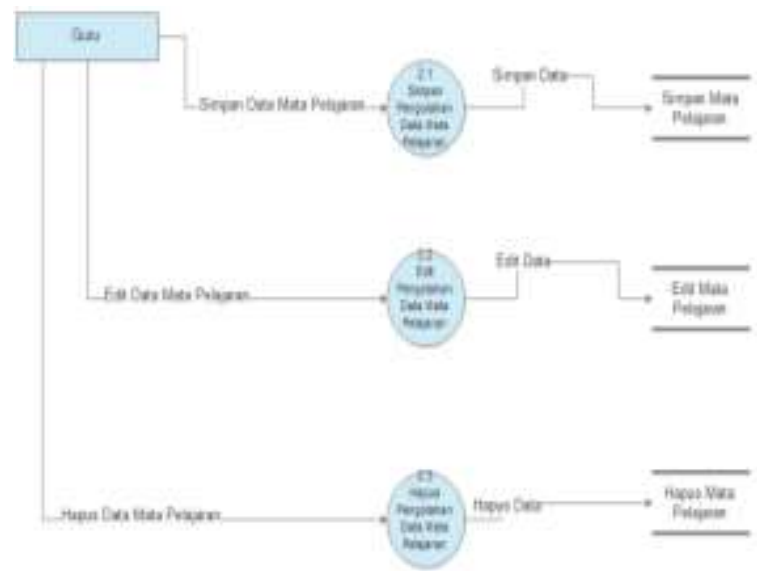

Gambar 3.5 DFD Level 2 Proses 1

Pada gambar 3.5 DFD Level ini terdiri dari beberapa proses, yaitu proses Simpan, Edit, dan Hapus yang digunakan oleh guru untuk dalam mengelola data mata pelajaran baru.

\subsection{DFD Level 2 Proses 2}

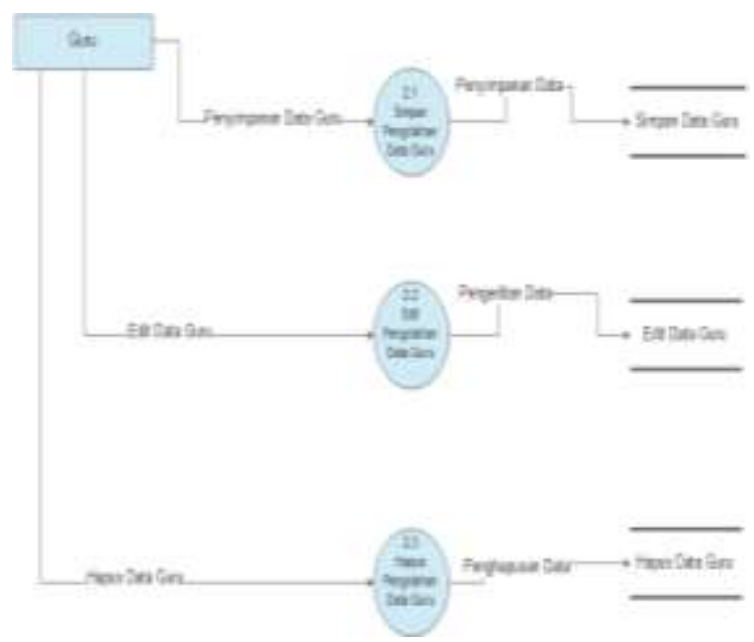

Gambar 3.6 DFD Level 2 Proses 2

Pada Gambar 3.6 DFD Level ini terdiri dari beberapa proses, yaitu proses Simpan, Edit, dan Hapus yang digunakan oleh guru untuk mengelola data guru baru. 


\subsection{DFD Level 2 Proses 3}

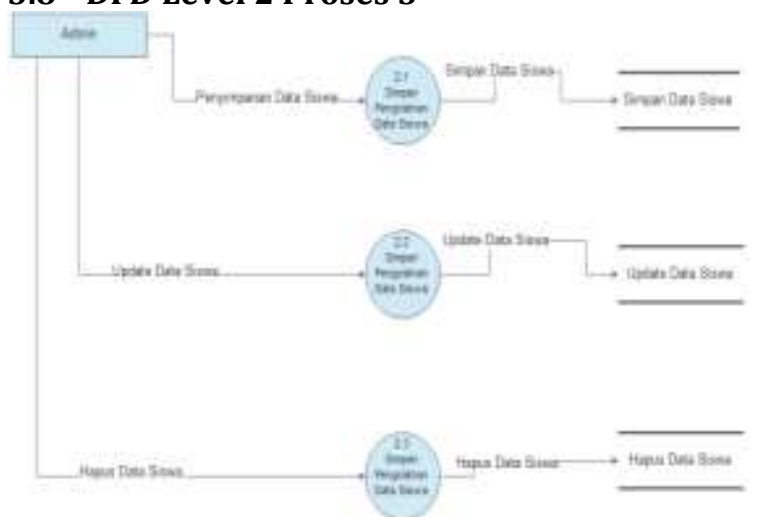

Gambar 3.7 DFD Level 2 Proses 3

Gambar 3.7 DFD Level ini terdiri dari beberapa proses, yaitu proses Simpan, Edit, dan Hapus yang digunakan oleh guru-guru untuk mengelola data siswa.

\subsection{DFD Level 2 Proses 4}

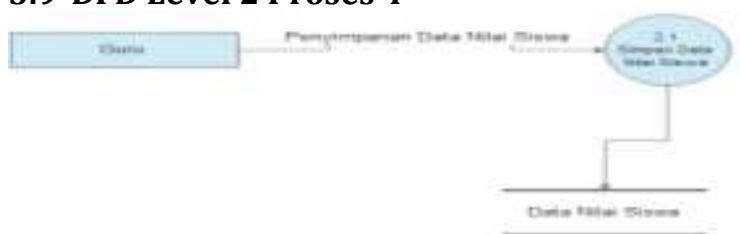

Gambar 3.8 DFD Level 2 Proses 4

Gambar 3.8 DFD Level ini terdiri dari proses simpan, yang digunakan oleh guru dalam mengelola data nilai siswa.

\subsection{DFD Level 2 Proses 4 (Pengolahan Laporan)}

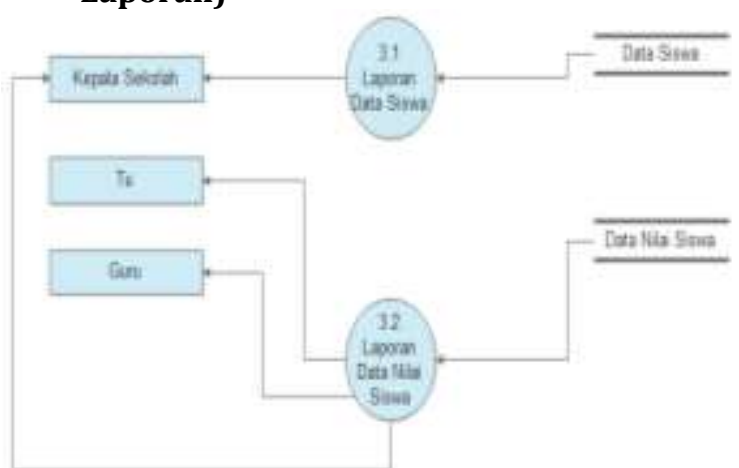

\section{Gambar 3.9 DFD Level 2 Proses 4 (Pengolahan Laporan)}

Seperti hasil rancang gambar 3.9 diatas, DFD Level ini menggambarkan tentang proses hasil laporan yang terjadi dan diterima oleh kepala sekolah, tu, dan guru yaitu, berupa laporan data siswa dan data nilai siswa yang berasal dari masing-masing database yang telah dirancang sebelumnya.

\subsection{Relasi Antar Tabel}

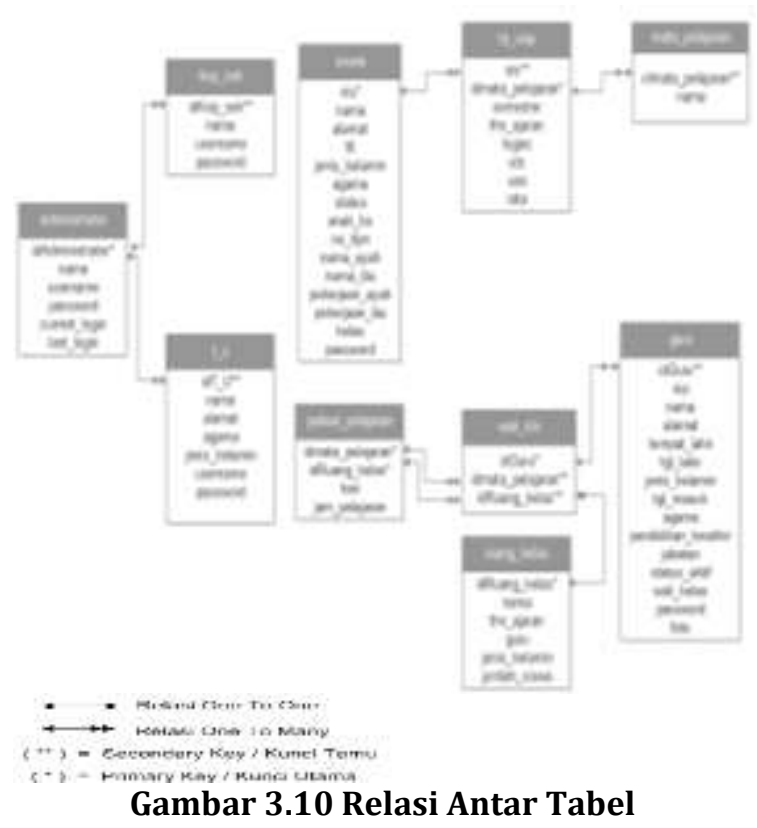

Menggambarkan hubungan antar tabel yang ada pada sistem yang saling berelasi antara satu tabel dengan tabel yang lainnya.

\subsection{Perancangan Halaman Login}

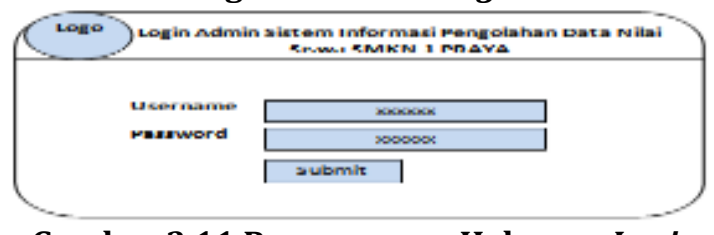

Gambar 3.11 Perancangan Halaman Login

Halaman ini berfungsi untuk login oleh masing-masing pengguna dan digunakan untuk verifikasi data pengguna dalam mengakses halaman admin.

\subsection{Perancangan Halaman Utama}

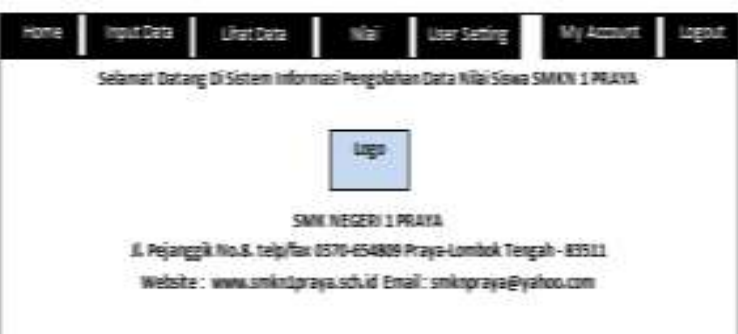

Gambar 3.12 Perancangan Halaman Utama

Halaman ini berfungsi sebagai area kerja pada pengolahan data nilai siswa dan digunakan untuk menampilkan menu-menu apa saja yang ada dihalaman utama. 


\section{Implementasi Dan Pembahasan}

\subsection{Halaman Login}

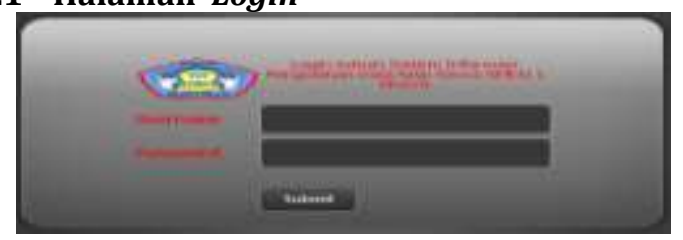

Gambar 4.1 Halaman Login

Pada tampilan awal aplikasi akan tampil frame login admin. Frame login admin hanya digunakan oleh TU dan kepala sekolah yang memiliki hak akses dalam menggunakan sistem. Untuk bisa masuk kehalaman utama, admin harus terlebih dahulu mamasukan username dan password kalau password dan username benar maka halaman utama bisa dibuka.

\subsection{Form Menu Utama}

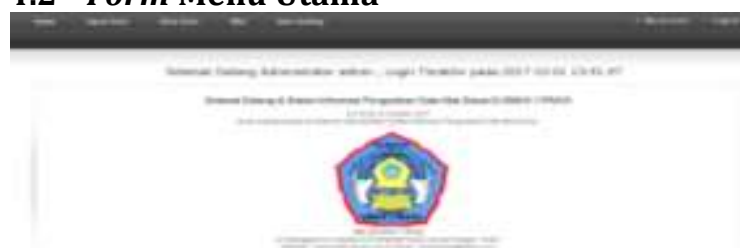

Gambar 4.2 Form Menu Utama

Form menu utama merupakan tampilan secara keseluruhan menu-menu yang ada pada sistem pengolahan data nilai siswa berbasis website. Form menu utama terdiri dari beberapa menu, yaitu menu home, input data, lihat data, nilai, user setting, my account, dan logout.

\section{Kesimpulan Dan Saran}

\subsection{Kesimpulan}

Berdasarkan uraian hasil dari pembahasan penulis dapat mengambil kesimpulan dari merancang bangun "Sistem Informsi Pengolahan Data Nilai Siswa Berbabsis Web di SMKN 1 PRAYA" diantaranya adalah sebagai berikut:

1. Kelebihan dari sistem yang diusulkan bila dibandingkan dengan sistem yang sedang berjalan terletak pada proses pengolahan data nilai ini berbasis web dan menggunakan komputer sebagai alat bantunya, sehingga pengolahan data pada sistem informasi pengolahan data nilai dapat dilakukan dengan mudah, cepat, dan data yang di olah menjadi lebih akurat.

2. Perancangan sistem informasi pengolahan data nilai berbasis web ini dapat menjadi solusi bagi para guru dalam mengolah data nilai yang sebelumnya manual menjadi terkomputerisasi serta menjadi sarana yang tepat dalam mengembangkannya menjadi sistem informasi berbasis online.

3. Dengan adanya sistem informasi pengolahan data nilai siswa ini semoga dapat berjalan dengan baik sehingga kedepannya dapat di kembangkan menjadi lebih baik lagi.

\subsection{Saran}

Berdasarkan kesimpulan diatas, maka penulis menyadari bahwa Sistem Informasi Pengolahan Data Nilai Siswa Berbasis Web Di SMKN 1 PRAYA ini masih perlu disempurnakan oleh karena itu ada beberapa saran yang perlu dipertimbangkan diantaranya:

1. Pada data siswa dan guru sebaiknya di tambahkan foto siswa.

2. Perlu adanya penambahan jumlah data terutama pada data nilai siswa yang di proses melalui sistem informasi pengolahan data nilai siswa berbasis web di SMKN 1 PRAYA.

\section{DAFTAR PUSTAKA}

Al-Bahra bin Ladjamuddin. Konsep Sistem Basis Data dan Impelementasinya. Yogyakarta: Grahallmu. 2004.

Ajiyati (2015), "pengembangan sistem informasi sekolah di SMP Negeri 2 Bambanglipuru". Betha Sidik, Ir.,2004.Pemrograman Web dengan PHP.Bandung: Informatika.

Dengen \& Marissa (2015), "sistem informasi sekolah berbasis web di SMP Negeri 4 Samarinda".

Effendi (2009), "Pengembangan Sistem Informasi Sekolah" (Bandung: Remaja Rosdakarya). Gunadarma. "Perancangan Sistem Informasi Pengolahan Data Nilai Siswa di SMKN2Pacitan".

Jogiyanto, HM. 2005. Analisis dan Desain Sistem Informasi: Pendekatan Terstruktur Teori dan Praktik Aplikasi Sekolah. Yogyakarta: Andi.

Hodia, Maelani, and Khairul Imtihan-STMIK Lombok. "Perancangan Sistem Informasi Praktek Klinik Kebidanan (PKK) Pada Prodi DIII Kebidanan Stikes Qamarul Huda." IJNSIndonesian Journal on Networking and Security 6.3 (2017).

Imtihan, Khairul, Rabiatul Hadawiyah, and Hasyim Asyari-STMIK Lombok. "Sistem Informasi Penggajian Guru Honorer Menggunakan Konsep Agile Software Development dengan Metodologi Extreme Programming (XP) pada SMK Bangun Bangsa." IJNS-Indonesian Journal on Networking and Security 7.2 (2018). 
Prayadi, Fendi, Khairul Imtihan, and Hairul Fahmi. "Sistem Informasi Monitoring Data Debit Daerah Irigasi Dengan Metode Pengukuran Debit Sesaat (Studi Kasus: Bendungan Batujai Kecamatan Praya Barat Kabupaten Lombok Tengah, NTB)." Jurnal Manajemen Informatika dan Sistem Informasi 1.1 (2018): 39-45.

Khairul Imtihan. "Perencanaan Strategi Sistem Informasi Pendidikan Pada Sekolah Tinggi Manajemen Informatika dan Komputer (STMIK) Lombok." Bianglala Informatika 3.2 (2015).

Melan Susanti STMIK Nusa Mandiri Jakarta, melan.msu@bsi.ac.id Jurnal Informatika, Vol.III No.1 April 2017.
Mcfadden.dkk (1990), mendefinisikan informasi sebagai data yang telah di proses sedemikian rupa.

Nugroho, Bunafit. Membangun Sistem Informasi Berbasis WEB dengan PHP dan MySQL. Yogyakarta:Gava Media.2008

Nursahid. Perancangan Sistem Informasi Penilaian Hasil Belajar Siswa Sekolah Menengah Atas (SMA) NEGERI 2 REMBANG Berbasis Web. [11] Seruni FTI UNSA 2012 Volume 1, ISSN: 2302-1136 - 2088-0154. Di Akses Pada 10 februari 2017

Silfyanti, Widya. 2003. Pengembangan Sistem Informasi Berbasis Web. Yogyakarta: Pustaka Belajar. 